Jurnal Penelitian dan Pengabdian Kepada Masyarakat Bidang ilmu Pendidikan

\title{
Strategi dalam Meningkatkan Aktivitas dan Hasil Belajar Fisika Siswa Kelas XI SMA Negeri 2 Woja melalui Pembelajaran Kooperatif Tipe Think Pair Share
}

\author{
Efendi \\ Guru SMA Negeri 2 Woja, Kabupaten Dompu, Nusa Tenggara Barat \\ E-mail: efendisma2wojadompu@gmail.com
}

Article History: Received: 2021-01-05 || Revised: 2021-02-15 || Published: 2021-03-21
Sejarah Artikel : Diterima: 2021-01-05 || Direvisi: 2021-02-15 || Dipublikasi: 2021-03-21

\begin{abstract}
This research is a Classroom Action Research using the Think-Pair-Share (TPS) Type of Cooperative Learning. This classroom action research was carried out in two (2) cycles, the sample used in this study were students of Class XI IPA.3 SMAN 2 Woja Semester I Academic Year 2020/2021, totaling 30 students. Actions are carried out in 2 cycles with subject matter covering the first cycle of 7.4 Mastering the subject matter of the effect of heat on substances and in the second cycle of 8.1 Mastering the subject matter of static fluid law. The research data in the form of student learning activities were collected using the observation method using the observation format and student learning outcomes were collected using learning outcome tests, based on the results of the data analysis conducted showed an increase in activity from an average score of 1.80 with the category of less active in cycle I was categorized as quite active in cycle II with an average score of 2.01 . Learning outcomes have increased from before the study with an average of 62.00 to 66.93 in the first cycle and 73.25 in the second cycle with completeness achieved by $65.67 \%$ before the study to $77 \%$ in the first cycle and $87 \%$ in the second cycle. complete classification is not finished yet becomes complete.
\end{abstract}

Keywords: Activities, Learning Outcomes, Physics, Think, Pair, Share

\begin{abstract}
Abstrak
Penelitian ini merupakan Penelitian Tindakan Kelas (PTK) dengan menggunakan Pembelajaran Kooperatif Tipe Think-Pair-Share (TPS). Penelitian tindakan kelas ini dilaksanakan dalam dua (2) siklus, Sampel yang digunakan dalam Penelitian ini yaitu Siswa Kelas XI IPA.3 SMAN 2 Woja Semester I Tahun Pelajaran 2020/2021 yang berjumlah 30 orang siswa. Tindakan dilakukan dalam 2 siklus dengan materi pelajaran meliputi pada siklus I tentang 7.4 Menguasai materi pelajaran pengaruh kalor terhadap zat dan pada siklus II tentang 8.1 Menguasai materi pelajaran hukum fluida statis. Data hasil penelitian berupa Aktivitas belajar siswa yang dikumpulkan dengan metode observasi yang menggunakan format observasi dan hasil belajar siswa dikumpulkan dengan menggunakan tes hasil belajar, berdasarkan hasil analisis data yang dilakukan menunjukkan adanya peningkatan aktivitas dari skor rata-rata 1,80 dengan katagori kurang aktif pada siklus I menjadi katagori cukup aktif pada siklus II dengan skor rata-rata 2,01. Untuk hasil belajar mengalami peningkatan dari sebelum penelitian dengan rata- rata 62,00 menjadi 66,93 pada siklus I dan $\mathbf{7 3 , 2 5}$ pada siklus II dengan ketuntasan yang dicapai $65.67 \%$ sebelum penelitian menjadi $77 \%$ pada siklus I dan $87 \%$ pada siklus II dari klasifikasi tuntas belum tuntas menjadi tuntas.
\end{abstract}

Kata kunci: Aktivitas, Hasil Belajar, Fisika, Think, Pair, Share

\section{PENDAHULUAN}

Tujuan Pendidikan Menengah atas maupun kejuruan adalah meningkatkan kecerdasan, pengetahuan, kepribadian, akhlak mulia, serta ketrampilan untuk hidup mandiri dan mengikuti pendidikan lebih lanjut sesuai dengan kejuruannya. Fisika sebagai salah satu cabang ilmu pengetahuan alam yang mendasari perkembangan teknologi maju dan merupakan pelajaran adatif yang bertujuan untuk membekali siswa pengetahuan dasar tentang hukum-hukum alam untuk mengantarkan siswa mencapai kompetensi program keahliannya. Hal tersebut mengajak kita selaku guru pada setiap satuan pendidikan untuk berupaya memberikan yang terbaik kepada siswa agar dapat menguasai disetiap kompetensi .Penguasaan tersebut dicerminkan pada hasil belajar, 
Berdasar pada pengalaman dan refleksi dalam pengelolaan pembelajaran fisika di awal semester 3 di kelas XI IPA.3 di SMAN 2 Woja tahun pelajaran 2020/2021 ditemui bahwa aktivitas siswa dalam mengikuti proses pembelajaran fisika kurang aktif, hal tersebut dibuktikan dengan rendahnya kontribusi siswa saat proses pembelajaran berlangsung. dan peran serta siswa masih didominasi oleh siswa yang memiliki kemampuan lebih. Sementara itu siswa yang kurang mampu tidak memberikan aktivitas disetiap menyelesaikan masalah yang diberikan. Disamping itu juga hasil belajar siswa di kelas tersebut menunjukkan hasil yang tidak memuaskan dibuktikan dengan nilai yang diperoleh siswa rata-rata masih relatif rendah. Jika hal tersebut dibiarkan tentu siswa yang tidak mampu akan terbelakang yang akhirnya akan berdampak pada makna belajar dan ketercapaian hasil belajar siswa tidak maksimal.

Berdasar pada kenyataan diatas maka perlu adanya alternatif penyelesaian yang memungkinkan sehingga mata pelajaran fisika lebih menyenangkan dan terbantu sehingga akan tumbuh rasa nyaman belajar siswa. Alternatif model pembelajaran yang digunakan yaitu pembelajaran kooperatif tipe Think-Pair-Share (TPS) yang dikembangkan oleh Kagan dalam (Lie, A, 2002) mengajarkan siswa untuk lebih mandiri dalam mengerjakan soal-soal yang diberikan sehingga dapat membangkitkan rasa percaya diri siswa dimana siswa dapat bekerjasama dengan orang lain dalamkelompok kecil yang heterogen. Melalui model pembelajaran ini diharapkan dapat menyelesaikan masalah tersebut sehinga pembelajaran lebih bermakna dan menyenangkan, dan siswa yang kurang mampu terbantu dalam kelompoknya untuk ikut berpikir, berdiskusi dan saling tukar pikiran dengan siswa yang mampu sehingga dalam menyelesaikan setiap masalah dapat teratasi dan menjadikan suasana pembelajaran lebih aktif.

\section{METODE PENELITIAN}

Penelitian ini merupakan Penelitian Tindakan Kelas (PTK) dengan menggunakan Pembelajaran Kooperatif Tipe Think-Pair-Share (TPS). Penelitian tindakan kelas ini dilaksanakan dalam dua (2) siklus, Setiap siklus terdiri dari empat tahapan yaitu: (1) Tahap perencanaan tindakan yang terdiri dari menyiapkan administrasi guru yang terdiri dari: silabus, program tahunan, program semester, rencana pelaksanaan pembelajaran (RPP), agenda dan jurnal, buku nilai dan analisis ulangan, menyususun tes hasil belajar dan instrumen penilaian yang berupa observasi, menyiapkan rancangan pembelajaran yang menyangkut strategi pembelajaran kooperatif tipe Think-Pair-Share yaitu: (1) mengelompokkan siswa yang beranggotakan 2 orang yang terdiri dari 1 siswa dengan krateria mampu dan 1 siswa dengan krateria kurang mampu, (2) Tahap pelaksanaan tindakan terdiri dari: a) Kegiatan pendahuluan yaitu menjadikan suasana kelas yang terfokus dan tertib dalam mengikuti proses pembelajaran serta mengkaitkan materi terdahulu dengan sekarang, b). Kegiatan inti yaitu pelaksanaan pembelajaran dengan menggunakan Pembelajaran Kooperatif tipe Think-Pair-Share, c) Kegiatan akhir yaitu Guru memberikan kesimpulan dan pada pertemuan ketiga diakhir pelajaran diberikan tes uraian, (3) Tahap observasi tindakan dilaksanakan saat proses pembelajaran berlangsung dan evaluasi dilaksanakan diakhir siklus dan (4) Tahap refleksi siklus dilakukan pada setiap akhir siklus yang bertujuan untuk melihat apakah pelaksanaan tersebut telah sesuai dengan prosedurnya. Sebagai dasar refleksi disetiap akhir siklus adalah kelebihan proses pembelajaran ini yang perlu dipertahankan dan hambatan atau kendala yang dialami dalam pembelajaran kooperatif tipe Think-Pair-Share (TPS ). Penelitian dilakukan pada semester 3 tahun pelajaran 2020/2021 yang berlokasi di SMAN 2 Woja dengan subjek penelitian adalah siswa kelas XI IPA.3 dengan jumlah siswa sebanyak 30 orang yang terdiri dari 27 siswa lakilaki dan 3 siswa perempuan. Data dikumpulkan dengan cara a). untuk aktivitas belajar siswa dengan lembar observasi dilakukan disetiap pertemuan, b). untuk hasil belajar dilakukan dengan memberikan tugas pada pertemuan II dan tes hasil belajar pada akhir siklus atau pertemuan III. 
Data dianalisis secara diskriptif kualitatif berdasarkan hasil observasi dan refleksi . Data hasil observasi diolah dengan rumus:

$$
\operatorname{Skor}(X)=\frac{\left(\mathbf{n}_{1} \times 1\right)+\left(\mathbf{n}_{2} \times 2\right)+\left(\mathbf{n}_{3} \times 3\right)}{(\text { banyaknya siswa }) \times(\text { banyaknya item })}
$$

Untuk data hasil belajar siswa dianalisis secara diskriptif yaitu dengan menentukan skor ratarata hasil tes ( M ) yang selanjutnya dikonversikan kedalam skala 100. berdasarkan Kriteria Ketuntasan Minimal (KKM), KKM untuk mata pelajaran fisika yang ditetapkan adalah 65 ( siswa dinyatakan tuntas belajar jika memperoleh nilai $\geq 65$ ) dan Kelas dinyatakan tuntas belajar apabila $85 \%$ telah memperoleh nilai 65 .

\section{HASIL DAN PEMBAHASAN}

Selama proses tindakan berlangsung dilakukan pengamatan pada lembar observasi ,memeriksa tugas dan hasil ulangan yang telah dianalisis seperti pada tabel berikut :

a) Aktivitas siswa hasil analisis data aktivitas siswa kelas XI IPA.3 SMAN 2 Woja yang mengikuti pembelajaran fisika menggunakan model kooperatif Tipe Think-Pair-Share mengalami peningkatan dari katagori kurang aktif menjadi cukup aktif (seperti pada tabel 1) berikut ini:

Tabel 1. Rekapitulasi Aktivitas Siswa

\begin{tabular}{ccccc}
\hline No & Siklus & Aktivitas Siswa & Katagori & Keterangan \\
\hline 1 & I & 1,80 & Kurang aktif & TT \\
\hline 2 & II & 2,01 & Cukup aktif & T \\
\hline
\end{tabular}

\section{Keterangan:}

T: Tuntas

TT: Tidak Tuntas

b) Hasil belajar siswa selama 2 siklus dilakukan mengalami peningkatan seperti pada tabel 2 berikut ini:

Tabel 2. Data Hasil Belajar Siswa

\begin{tabular}{ccccc}
\hline No & Siklus & Hasil Belajar & Ketuntasan Klasikal & Keterangan \\
\hline 1 & Pra siklus & 62,00 & $65.67 \%$ & TT \\
\hline 2 & I & 66,93 & $77 \%$ & TT \\
\hline 3 & II & 73,25 & $87 \%$ & T \\
\hline
\end{tabular}

\section{Keterangan:}

T: Tuntas

TT: Tidak Tuntas

Berdasarkan hasil observasi yang berupa data hasil belajar siswa selama pelaksanaan pembelajaran pada siklus I, diperoleh bahwa pada awal pelaksanaan model pembelajaran Kooperatif Tipe Think-Pair-Share ditemukan beberapa hambatan diantaranya: a). ada kelompok yang belum maksimal dalam kerjasam kelompok untuk meemecahkan masalah yang diberikanakbat dari pembagian kelompok yang kurang merata tingkat kemampuan sehingga dalam melaksanakan aktivitas kelompok ada yang diam dan ada yang aktif, b). belum terbiasanya siswa menyampaikan ide akibat dari adanya rasa malu dalam mengemukakan pendapat sehingga apa yang dipikirkan dengan apa yang sampaikan tidak sesuai, c). Pengelolaan kelas yang kurang 
optimal karena belum terbiasa. Hambatan-hambatan tersebut dijadikan bahan pertimbangan dalam menyusun kegiatan pembelajaran pada siklus II. Berdasarkan hasil observasi dan hasil belajar selama pelaksanaan pembelajaran pada siklus II menunjukkan adanya peningkatan aktivitas dan hasil belajar siswa dengan memperkecil hambatan atau kendala yang dihadapi pada siklus I antara lain komunikasi yang tumbuh pada setiap kelompok karena adanyan pemerataan kemampuan siswa sehingga aktivitas pembelajaran lebih kelihatan.

\section{SIMPULAN DAN SARAN}

\section{A. Simpulan}

Berdasarkan rumusan masalah, tujuan, dan hasil penelitian seperti yang telah diuraikan di atas maka dapat ditarik kesimpulan sebagai berikut:

1. Penerapan model pembelajaran Kooperatif Tipe Think-Pair-Share dalam pembelajaran fisika di kelas XI IPA.3 SMAN 2 Woja ternyata dapat meningkatkan aktivitas siswa dari kategori kurang menjadi cukup aktif.

2. Penerapan model pembelajaran Kooperatif Tipe Think-Pair-Share dalam pembelajaran fisika di kelas XI IPA.3 SMAN 2 Woja dapat meningkatkan hasil belajar dari belum tuntas menjadi tuntas.

\section{B. Saran}

Beberapa saran yang dapat penulis berikan yaitu:

1. Dapat direkomendasikan kepada Guru untuk menggunakan model pembelajaran ini karena dapat memberikan gambaran yang efektif dalam pengelolaan pembelajaran dikelas.

2. Untuk memperoleh kualitas pembelajaran yang lebih baik maka pihak pengelola di sekolah mengubah seting kelas yang konvensional menjadi kelas yang dinamis, mudah diatur sesuai dengan pola pembelajaran yang diinginkan.

\section{DAFTAR RUJUKAN}

Asmedy. (2018). Pengembangan Perangkat Pembelajaran Bangun Datar dengan Pendekatan Open Ended. JIIP - Jurnal Ilmiah Ilmu Pendidikan, 1(2), 66-72. Retrieved from http://jiip.stkipyapisdompu.ac.id/jiip/index.php/JIIP/article/view/11

Asmedy. (2020). Perbandingan Hasil Belajar Connected Mathematics Project (CMP) dengan Pembelajaran Konvensional Pada Pokok Bahasan Geometri. JIIP - Jurnal Ilmiah Ilmu Pendidikan, 3(1), 456-464. Retrieved from http://jiip.stkipyapisdompu.ac.id/jiip/index.php/IIIP/article/view/131

Budiman, B., \& Arif, I. (2018). PENGEMBANGAN PERANGKAT PEMBELAJARAN BIOLOGI MODEL INKUIRI TERBIMBING BERKARAKTER BUDAYA LOKAL "NGGAHI RAWI PAHU" UNTUK MELATIHKAN KEMAMPUAN BERPIKIR KRITIS SISWA SMA. BIOEDUKASI, 9(2), 109-123.

Dahar, Ratna Wilis, 1989. Teori-Teori Belajar. Jakarta. Penebit Erlangga.

Depdiknas, 2005. Materi Pelatihan Terintegrasi Ilmu Pengetahuan Alam. Direktorat Jendral Pendidikan Dasar dan Menengah .

Dimyati dan Mudjiono, 2006. Belajar dan Pembelajaran. Cetakan Ketiga .Jakarta. Penerbit Rineka Cipta.

Eka Yulianti, \& Taufik. (2020). Studi Perbandingan Eksistensi Alam Pada Novel Tanah Baru Tanah Air Kedua Karya Nh. Dini Dan Sri Rinjani Karya Eva Nourma (Tinjauan Ekologi Sastra). Ainara Journal (Jurnal Penelitian Dan PKM Bidang Ilmu Pendidikan), 1(2), 44-55. https://doi.org/10.1234567/ainarajournal.v1i2.13 
Fathirma'ruf, Budiman, \& Asmedy. (2019). Analisis Validitas dan Reliabilitas Keterbacaan Buku Ajar perkuliahan Berbasis Analogi. JIIP - Jurnal Ilmiah Ilmu Pendidikan, 2(3), 336-340. Retrieved from http://jiip.stkipyapisdompu.ac.id/jiip/index.php/IIIP/article/view/67

Fathirma'ruf, F., \& Said, M. B.(2020). Pengembangan Perangkat Pembelajaran Konstruktivistik Model Teaching with Analogies (TWA) pada Mata Kuliah Database Management System (DBMS) untuk Meningkatkan Kemampuan Berpikir Kreatif Mahasiwa. Jurnal Teknologi Informasi dan Ilmu Komputer, 7(5), 1051-1060.

Lie, A. 2002. Cooperative Learning, Gramedia Wdyasarana Indonesia ,Jakarta

Nurkancana, W dan Sunartana, 1992. Evaluasi hasil belajar. Surabaya : Usaha Nasional.

Rasuki, M. (2017). The Incidental Acquisition of English Nominal Structures by a Young EFL Learner under Comprehension-based Lessons. International Journal of Applied Linguistics and English Literature, 6(4), 45-51. doi:http://dx.doi.org/10.7575/aiac.ijalel.v.6n.4p.45.

Sadra, I Wayan . 1996. Peningkatan Ketrampilan Berhitung pada siswa Sekolah Dasar Melalui Pemanfaatan Media Konkret Sebagai Sarana Relajar. Laboran Penelitian STKIP Singaraja.

Santyasa Wayan, dkk. 2005. Pedoman Guru pembelajaran Teks Fisika Bermuatan model Perubahan Konseptual dan Komunitas Belajar. Produk RUKK Menristek Tahun 2005 IKIP Negeri Singaraja.

Sudjana, 1992. Metode Statistik, Bandung : Tarsito Bandung.

Sudjana, Nana. 2004. Penilaian Hasil Proses Belajar Mengajar. Bandung.Remaja Rosdakarya.

Suharsimi Arikunto, 2008. Dasar-dasar Evaluasi Pendidikan (Edisi Revisi), cetakan kedelapan, Penerbit Bumi Aksara.

Tabrani R, A dan ES.1992. Hamijaya. Pedoman Pelaksanaan CBSA dalam Prose Relajar Mengajar. Cetakan ketiga . Penerbit Nine Karya Jaya.

Wirartha, I Made . 2005. Pedoman Penulisan Usulan Penelitian Skripsi dan Tesis. Denpasar . Penerbit Andi Yogyakarta. 